\title{
PENGARUH RENDAMAN ASAM TERHADAP KUAT TEKAN BETON DENGAN PENAMBAHAN FLY ASH
}

\author{
Mufti Amir Sultan ${ }^{1)}$, Imran $^{2)}$, Muhammad Faujan ${ }^{3)}$ \\ Program Studi Teknik Sipil, Universitas Khairun \\ Email: muftiasltn@unkhair.ac.id ${ }^{1)}$, namakuimo@hotmail.com ${ }^{2)}$, \\ faujanlaher007@gmail.com ${ }^{3)}$
}

DOI: http://dx.doi.org/10.29103/tj.v11i1.367

(Received: August 2020 / Revised: December 2020 / Accepted: December 2020)

\begin{abstract}
Abstrak
Beton memiliki kuat tekan yang tinggi yang merupakan sifat paling utama dan mencerminkan kemampuan beton menahan beban tekan yang diberikan kepadanya, namun lingkungan asam yang mengandung unsure kimia asam akan merusak beton secara perlahan- lahan mulai dari tepi dan sudut beton dengan terjadinya pelepasan butiran-butiran partikel beton sehingga beton menjadi keropos dan mengakibatkan terjadinya penurunan kuat tekan beton. Beton dengan bahan tambah fly ash menjadi tijauan khusus untuk lingkungan asam dikarenakan permeabilitas dan porositasnya yang kecil akan mempersulit serangan asam lebih parah lagi sampai ke inti beton. Penelitian ini bertujuan untuk mengetahui nilai kuat tekan beton dengan presentase penambahan butiran fly ash dengan kadar $20 \%$ terhadap berat seman, serta pengaruh lingkungan asam terhadap kuat tekan beton yang menggunakan bahan tambah fly ash. Hasil penelitian menunjukan beton normal (BN) mengalami penurunan kuat tekan yang bervariasi yaitu pada waktu 1 bulan sebesar 24,79\% dan 2 bulan sebesar 30,58\% dari beton normal umur 28 hari, sedangkan perlakuan air asam pada beton fly ash (BFA) juga mengalami penurunan kuat tekan pada waktu yang sama yaitu 1 bulan sebesar 2,61\% dan 2 bulan sebesar 26,80\% dari beton fly ash (BFA) umur 28 hari, di mana rasio penuruan pada beton fly ash lebih baik dibandingkan beton tanpa fly ash. Dengan demikian terlihat bahwa beton fly ash (BFA) lebih tahan terhadap serangan asam sulfat dibandingkan dengan Beton Normal (BN).
\end{abstract}

Kata Kunci: KuatTekan, Asam Sulfat, Fly Ash

\begin{abstract}
Concrete has a high compressive strength which is the most important characteristic and reflects the ability of the concrete to withstand the compressive load given to it, however an acidic environment that contains acidic chemical elements will slowly damage the concrete starting from the edges and corners of the concrete by releasing the particles. concrete so that the concrete becomes porous and results in a decrease in the compressive strength of theconcrete. Concrete with fly ash added material is of particular importance for acidic environments because its small permeability and porosity will make it more difficult for acid attack to reachthe concrete core. This study aims to determine the value of the compressive strength of concrete with the percentage of adding fly ash granules with a content of $20 \%$ to the weight of the cement, as well as the effect of the acidic environment on the compressive strength of concrete using fly ash added. The results showed that normal concrete (BN) experienceda varying decrease in compressive strength, namely at 1 month of $24.79 \%$
\end{abstract}


and 2 months of $30.58 \%$ of normal concrete aged 28 days, while the treatment of acid water on fly ash concrete (BFA) also experienced a decrease in compressive strength at the same time, namely 1 month of $2.61 \%$ and 2 months of $26.80 \%$ of fly ash concrete (BFA) 28 days old. Where the reduction ratio in fly ash concrete is better than concrete without fly ash. Thus it can be seen that fly ash concrete (BFA) is more resistant to sulfuric acid attack than Normal Concrete (BN).

Keywords: Compressive Strength, Sulfuric Acid, Fly Ash

\section{Latar Belakang}

Diketahui bahwa biaya produksi semen itu mahal, menghabiskan energi yang tinggi, menghabiskan sumber daya alam dan mengeluarkan gas rumah kaca dalam jumlah besar. Oleh karena itu teknologi beton difokuskan pada alternatif lain yang dapat digunakan sebagai bahan pengganti atau bahan tambah semen pada produksi beton. Para peneliti telah mencari sepanjang waktu untuk bahan pengganti atau bahan tambah semen yang murah dan mudah tersedia, seperti limbah pembangkit listrik tenaga uap yang memanfaatkan batu bara sebagai sumber energy, di mana pada wilayah Maluku Utara terdapat pembangkit yang menggunakan batu bara sebagai sumber energy yaitu pembangkit listrik Rum Tidore Kepulauan (Sultan, Imran, \& Faujan, 2019).

Beton masih menjadi material pilihan utama oleh para perancang dalam pembuatan struktur. Disebabkan kemudahan dalam memperoleh material penyusunannya, serta beton juga memiliki kekuatan tekan yang baik, di mana kekuatan tekan ini merupakan salah satu kinerja utama dari beton. Beton dapat dimanfaatkan sebagai infrastrukutur tranportasi seperti jembatan, perkerasan kaku, apron pada bandar udara dan pelabuhan.Infrastruktur pengolahan air limbah, jaringan irigasi, breakwater dan lain sebagainya. Pemakaian beton pada lingkungan agresif sangat berpengaruh pada keawetan dan dapat menyebabkan kerusakan serta penurunan kekuatan tekan beton (Amir Sultan, Parung, Tjaronge, \& Djamaluddin, 2015), (Sultan \& Djamaluddin, 2017). Struktur beton dapat dikatakan berada pada lingkungan agresif apabila beton terus-menerus berada dalam tanah, lingkungan air laut, dan daerah industry yang banyak terkandung sulfat, beton akan menjadi rentan terhadap serangan sulfat yang dapat mengurangi durabilitas beton (Suhana \& Mualifah, 2017).

Beton yang berada pada tanah yang terkontaminasi bahan kimia agresif dapat merusak bangunan bawah tanah seperti terowangan, basemant, struktur pondasi, bangunan pengolah air limbah ataupun bangunan penahan tanah. Penggunaan struktur beton yang kontak langsung dengan senyawa asam sulfat akan mempengaruhi kualitas kuat tekan beton karena asam sulfat dapat membuat beton menjadi korosi. Korosi sudah dikenal sejak lama dan sangat merugikan (Sultan, Gaus, Rakhman, \& Barmawi, 2020).

Beton yang berada pada lingkungan asam atau dipengaruhi oleh asam dapat menyebabkan penurunan kinerja beton seperti penurunan kuat tekan beton (Pandiangan, Olivia, \& Darmayanti, 2014), (Taku, Amartey, \& Kassar, 2015), (Sokołowska \& Woyciechowski, 2015). Oleh karena itu maka beberapa peneliti menggunakan fly ash atau abu terbang sebagai bahan tambah atau pengganti 
semen untuk mereduksi pengaruh asam antara lain: Modifikasi campuran dengan menggunakan slag pada bangunan peternakan yang menerima serangan dari asam laktat dan asam sulfat, menghasilkan bahwa beton dengan penambahan slag lebih tahan dibandingkan denga beton menggunkaan semen tanpa penambahan slag(Back \& Page, 2002). Penambahan abu terbang ke dalam campuran beton dengan kadar 10\% sampai 50\% dengan setiap kenaikan 10\% menunjukkan bahwa beton yang telah dicampur dengan abu terbang mempunyai ketahanan yang lebih baik dibandingkan beton tanpa campuran abu terbang terhadap pengaruh asam sulfat (Ahmad, 2011). Mengganti semen dengan fly ash dikombinasikan dengan fly ash ultra halus pada campuran beton di lingkungan asam dengan kadar asam sulfat 3\% dan asam nitra 1,5\%. Pada kadar 30\% fly ash dan $10 \%$ fly ash ultra halus mampu mereduksi kehilangan massa terendah (Barbhuiya \& Kumala, 2017). Penambahan kalsium hiroksida dan boraks pada beton yang terbuatdari $100 \%$ fly ash (high volume fly ash atau HVFA) menunjukkan bahwa boraks dapat memperbaiki kinerjia beton HVFA (Renaldo, Antoni, \& Hardjito, 2017).

Berdasarkan uraian tersebut maka penting pemanfaatan limbah batu bara yang dihasilkan dari hasil pembakaran PLTU Rum Kota Tidore Kepulauan untuk memperbaiki kinerja beton pada lingkungan asam atau pada struktur yang dipengaruhi oleh asam.

\section{Metode Penelitian}

\subsection{Tahapan pelaksanaan penelitian}

Penelitian dilakukan di Laboratorium Struktur dan Bahan, Jurusan Teknik Sipil, Fakultas Teknik Universitas Khairun. Dalam penelitian ini akan dibuat benda uji berbentuk silinder untuk pengujian kuat tekan.

Pengujian yang akan dilaksanakan dalam penelitian ini berupa pengujian bahan, pengujian beton segar dan pengujian beton keras (pengujian kuat tekan). Bahan tambah fly ashyang akan digunakan kadar 20\% terhadap berat semen dengan mutu beton rencana $25 \mathrm{MPa}$ (Sultan et al., 2019).

\subsection{Persiapan dan Survei Lokasi Pengambilan Material}

Lokasi pengambilan material agregat kasar, agregat halus dan fly ash dari wilayah Maluku Utara, adapun lokasi sebagai berikut:

a. Quarry Tubo pada wilayah Kecamatan Ternate Utara Kota Ternate, adalah quarry bahan baku agregat kasar berupa batu pecah.

b. Quarry Togafo pada wilayah Kecamatan Ternate Pulau Kota Ternate, adalah quarry agregat halus (pasir).

c. Abu terbang (fly ash) diperoleh dari hasil pembakaran PLTU yang terletak di Kelurahan Rum Kota Tidore Kepulauan

\subsection{Benda Uji}

Penelitian ini menggunakan benda uji berbentuk silinder berdiameter $15 \mathrm{~cm}$ dengan tinggi $30 \mathrm{~cm}$. Dengan penambahan variasi fly ash sebesar $20 \%$ untuk menentukan nilai kuat tekan terhadap persentasi fly ash dari berat semen. Benda uji direndam dalam air normal dan larutan asam sulfat kadar $2 \%$. Variasi benda uji seperti siperlihatkan pada Tabel 1. 
Tabel 1 Benda uji dengan penambahan fly ash $20 \%$

\begin{tabular}{ccccc}
\hline No & Kode Benda Uji & $\begin{array}{c}\text { Fly } \\
\text { Ash }(\%)\end{array}$ & $\begin{array}{c}\text { Jumlah Benda Uji } \\
\text { (buah) }\end{array}$ & Keterangan \\
\hline 1. & BN & 0 & 30 & air normal \\
\hline 2. & BFA & 20 & 30 & $\begin{array}{c}\text { Larutan asam sulfat } \\
\text { kadar 2\% }\end{array}$ \\
\hline
\end{tabular}

Pengenceran asam sulfat konsentrasi 2\% dihitung dengan rumus sebagai berikut:

$$
V_{1} N_{1}=V_{2} N_{2}
$$

Dengan:

$\mathrm{V} 1$ = Banyaknyalarutanmurniyang akandiambil

$\mathrm{N}_{1}$ = Konsentrasilarutan yang akankitaencerkan

$\mathrm{V}_{2}=$ Banyaknyalarutan yang akandibuatdalampengenceran

$\mathrm{N}_{2}=$ Konsentrasilarutansetelahdiencerkan

\subsection{Perendaman Benda Uji}

Untuk perlakuan benda uji terhadap perendaman larutan asam yaitu dengan meletakkan benda uji dalam bak yang terbuat dari pasangan batu. Lama perendaman 30 hari dan 60 hari. Benda uji dicuringselama 28 hari, setelah itu direndam dalam larutan asam, waktu perendaman itu adalah mulai perhitungan untuk perendaman 30 dan 60 hari atau 1 dan 2 bulan.

\subsection{Pengujian Kuat Tekan}

Pengujian dilakukan setelah benda uji mencapai umur perendaman dalam larutan asam dengan kadar $2 \%$ selama 30 hari dan 60 hari setelah perwatan selama 28 hari.Tahapan pengujian sebagai berikut:

1. Benda uji yang telah mencapai usia dipersiapkan.

2. Ditimbang untuk mendapatkan data berat silinder beton dalam keadaan kering.

3. Mengukur dimensi benda uji.

4. Meletakkan benda uji pada mesin uji desak yang diletakkan secara vertikal untuk uji desak dengan cara peletakan secara simetris.

5. Nyalakan mesin uji desak dengan tekanan yang dinaikkan secara berangsurangsur.

6. Pembebanan dilakukan sampai benda uji tidak kuat lagi menahan tekanan dan retak atau hancur.

Besar kuat tekan beton dihitung dengan menggunakan persamaan (2).

$$
f^{\prime} c=\frac{P}{A}
$$

Dengan:

$$
\begin{aligned}
& \mathrm{P}=\text { beban tekan }(\mathrm{kN}), \\
& \mathrm{A}=\text { luas bidang tekan }\left(\mathrm{mm}^{2}\right)
\end{aligned}
$$




\section{Hasil dan Pembahasan}

\subsection{Pengujian agregat}

Pengujian agregat yang dilakukan dalam penelitian ini meliputi pengujian kadar lumpur, kadar air, penyerapan, $\mathrm{Bj}$, dan modulus kehalusan serta keausan untuk agregat kasar. Hasil pengujian dirangkum dalam Tabel 2.

Tabel 2 Hasil pemeriksaan agregat halus dan agregat kasar

\begin{tabular}{clcc}
\hline No & \multicolumn{1}{c}{ Pengujian } & AgregatHalus & AgregatKasar \\
\hline 1. & Kadar lumpur & $0,50 \%$ & $0,50 \%$ \\
\hline 2. & Kadar air & $3,00 \%$ & $0,75 \%$ \\
\hline 3. & Penyerapan air & $3,60 \%$ & $1,50 \%$ \\
\hline 4. & Bj SSD & 2,38 & 2,46 \\
\hline 5. & Modulus kehalusan & $2,68 \%$ & $7,16 \%$ \\
\hline 6. & Keausan & -- & $29,40 \%$ \\
\hline
\end{tabular}

Sumber(Sultan et al., 2019)

\subsection{Kuat Tekan Beton Normal}

Hasil pengujian kuat tekan rata-rata beton normal $(\mathrm{BN})$ setelah benda uji diberi perlakuan dengan cara direndam di air tawar dan larutan asam sulfat $2 \%$ masing-masing memiliki hasil kuat tekan yang bervariasi, yang mana hasil kuat tekan akibat perlakuan tersebut ditunjukkan pada Gambar 1, di mana hasil pengujian menunjukan bahwa pada perlakuan air tawar hasil kuat tekan meningkat pada waktu 1 bulan sebesar $10,74 \%$ dan pada saat 2 bulan meningkat $12,40 \%$ dibandingkan dengan benda uji 0 bulan atau umur perawatan 28 hari.

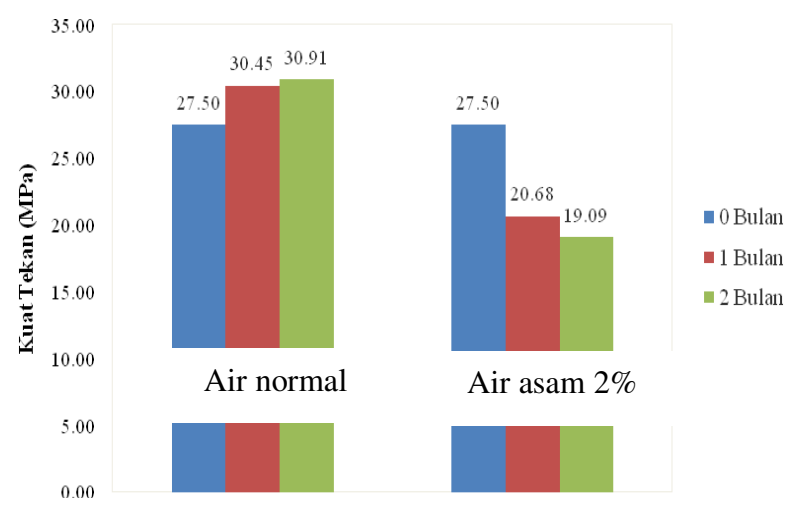

Gambar 1 Kuat tekan beton normal dengan waktu perendaman

Pada perlakuan perendaman dengan asam sulfat $2 \%$ menunjukan penurunan kuat tekan pada waktu 1 bulan sebesar $24,79 \%$ dan 30,58\% setelah direndam selama 2 bulan setelah perwatan 28 hari. Dari uraian tersebut terlihat bahwa air asam dapat menyebabkan penurunan kuat tekan.

\subsection{Kuat Tekan Beton 20\% Fly Ash}

Hasil pengujian kuat tekan rata-rata beton20\% fly ash (BFA) setelah benda uji diberi perlakuan dengan cara direndam di air tawar dan larutan asam sulfat $2 \%$ masing-masing memiliki hasil kuat tekan yang bervariasi, yang mana hasil kuat 
tekan akibat perlakuan tersebut ditunjukkan pada gambar 2, di mana hasil pengujian menunjukan bahwa pada perlakuan air tawar hasil kuat tekan meningkat pada waktu 1 bulan sebesar 9,15\% dan pada saat 2 bulan meningkat $11,76 \%$ dibandingkan dengan benda uji 0 bulan atau umur perawatan 28 hari.

Pada perlakuan perendaman dengan larutan asam sulfat $2 \%$ menunjukan penurunan kuat tekan pada waktu 1 bulan sebesar $2,61 \%$ dan $26,80 \%$ setelah direndam selama2 bulan setelah perawatan 28 hari. Dari uraian tersebut terlihat bahwa air asam dapat menyebabkan penurunan kuat tekan pada beton dengan penambahan fly ash sebesar $20 \%$ terhadap berat semen.

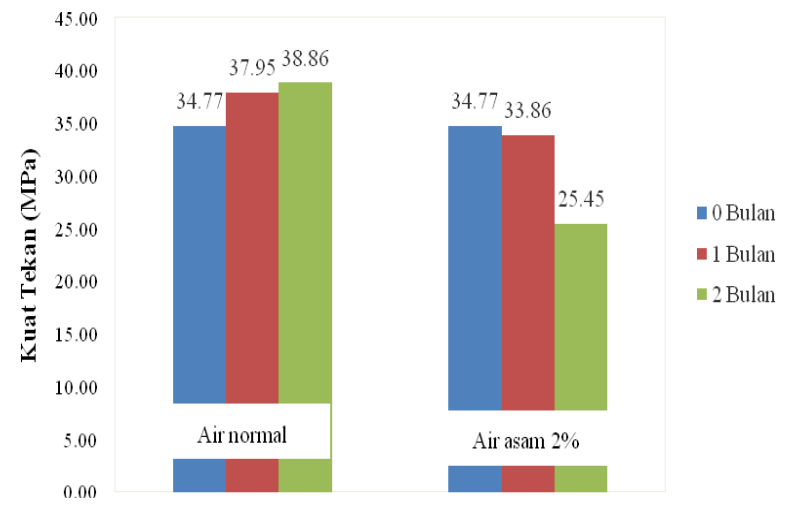

Gambar 2 Kuat tekan beton $20 \%$ fly ash dengan waktu perendaman

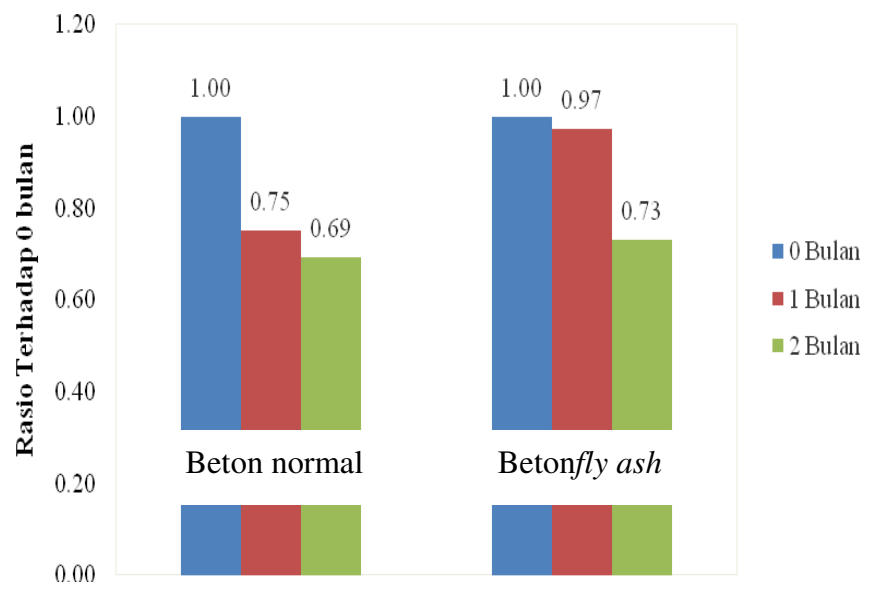

Gambar 3 Rasio penurunan kuat tekan terhadap beton 0 bulan pada perendaman larutan asam sulfat $20 \%$

Gambar 3 memperlihatkan rasio penurunan kuat tekan pada beton normal dan beton fly ash terhadap lama perendaman larutan asam sulfat $2 \%$. Beton normal maupun beton dengan bahan tambah fly ash akan mengalami degradasi kekuatan tekan seiring dengan lama perendaman pada air asam, namun dapat dilihat bahwa degradasi kekuatan tekan pada sampel mempunyai kecendungan rasio penurunan pada beton dengan penambahan fly ash lebih kecil dibandingkan dengan beton tanpa fly ash terhadap waktu perendaman. Ini mengindikasikan 
bahwa dengan penambahan fly ash dapat membantu untuk mempertahankan kuat tekan beton akibat pengaruh larutan asam.

\subsection{Pengamatan Visual Benda Uji}

Hasil pengamatan visual memperlihatkan kerusakan yang terjadi akibat serangan asam sulfat pada benda uji terbatas pada zona permukaan sampai ke kedalaman $2 \mathrm{~mm}$. Di bawah kedalaman zona ini, beton masih belum mengalami kerusakan. Hal ini dapat dikaitkan dengan perpindahan ion-ion asam dan sulfat dari larutan asam sulfat menuju ke dalam beton dimulai dari zona permukaan. Seiring dengan waktu zona yang ditembus oleh ion-ion tersebut semakin dalam sehingga kerusakan yang ditimbulkan juga bergerak dari permukaan menuju ke kedalaman beton. Namun demikian sampai pengamatan selama 2 bulan dalam rendaman asam sulfat, zona kerusakan yang ditimbulkan oleh kerusakan serangan asam sulfat hanya sampai pada kedalaman sekitar $2 \mathrm{~mm}$. Gambar 4 memperlihatkan contoh perbedaan visual beton normal (BN) dan beton fly ash (BFA) yang terserang larutan asam sulfat pada waktu 2 (dua) bulan.

Keruskan benda uji yang terendam dalam larutan asam sulfat seperti ditunjukkan pada gambar 4. Perbedaan tingkat kerusakan antara beton normal (BN) dan beton fly ash (BFA). Kerusakan pada beton normal (BN) akibat perendaman larutan asam sulfat terlihat cenderung lebih parah dibandingkan dengan beton fly ash (BFA), hal ini dikarenakan fly ash yang ditambahkan pada semen menjadi komponen paling halus sehingga dapat menjadi pengisi ronggarongga (filler) dalam beton dan menjadikan beton lebih padat, sehingga dapat memperlambat serangan sulfat pada beton fly ash (BFA).

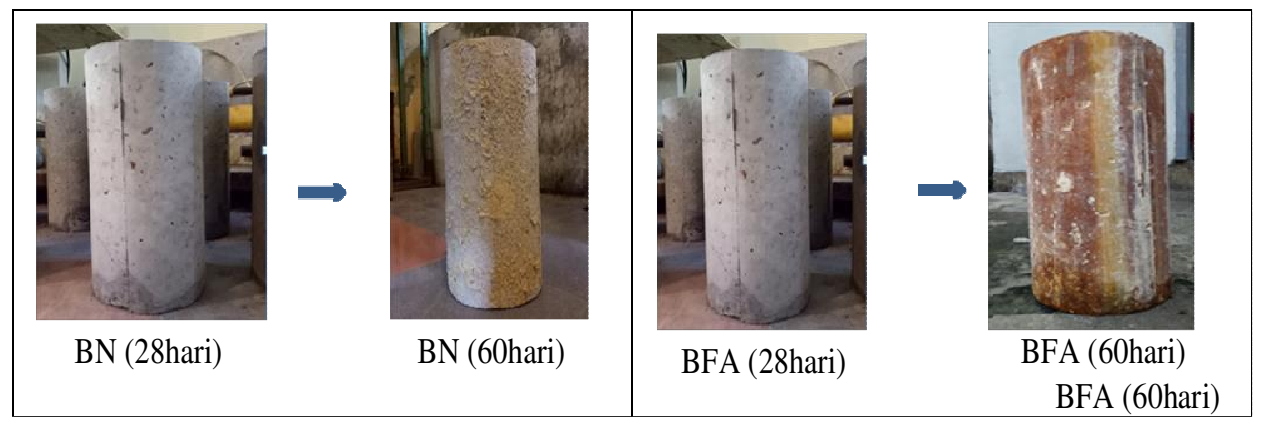

Gambar 4 Visual benda uji setelah direndam larutan asam

\section{Kesimpulan dan Saran}

Penambahan fly ash pada campuran beton dapat meningkatkan kemampuan beton dalam mereduksi pengaruh rendaman larutan asam sulfat kadar $2 \%$, terlihat dari rasio penuruan kuat tekan pada beton fly ash dengan dibandingkan dengan beton tanpa penambahan fly ash. 


\section{Daftar Kepustakaan}

Ahmad, I. 2011. Analisis Perbedaan Kuat Tekan Beton Tambahan Abu Terbang Dengan Beton Normal Yang Direndam Dalam asam Sulfat Untuk Beton Mutu Rendah. Konstruksia, 2(2), 23-30.

Amir Sultan, M., Parung, H., Tjaronge, W., \& Djamaluddin, R. 2015. Effect of Marine Environment to the Concrete Beams Strengthened Using GFRP Sheet. International Journal of Engineering and Technology, 7(1), 21-24. https://doi.org/10.7763/IJET.2015.V7.759

Back, G., \& Page, N. 2002. Accelerated Degradation Testing Of Concrete In Acidic Environment $\square$ : Resistance To Lactic And Sulfuric Acid. 9Dbmc2002, 1-10.

Barbhuiya, S., \& Kumala, D. 2017. Behaviour of a sustainable concrete in acidic $\begin{array}{llll}\text { environment. Sustainability } & \text { (Switzerland), }\end{array}$ https://doi.org/10.3390/su9091556

Pandiangan, J. A., Olivia, M., \& Darmayanti, L. 2014. Ketahanan Beton Mutu Tinggi Di Lingkungan Asam. Jurnal Online Mahasiswa (JOM) Bidang Teknik Dan Sains, 1(1), 1-11.

Renaldo, R., Antoni, P., \& Hardjito, D. 2017. Ketahanan di lingkungan asam, kuat tekan dan penyusutan beton dengan $100 \%$ fly ash tanpa aktivator. Jurnal Dimensi Pratama Teknik Sipil, 6(1), 1-7.

Sokołowska, J. J., \& Woyciechowski, P. 2015. Effect of acidic environments on cement concrete degradation. Third International Conference on Sustainable Constructions Materials and Technologies, (August 2013), 1-11.

Suhana, N., \& Mualifah, A. 2017. Pengaruh Rendamana Air Asam Sulfat Pasca Curing Terhadap Kuat Tekan Beton: Gema Wiralodra, 8(1), 42-51.

Sultan, M. A., \& Djamaluddin, R. 2017. Pengaruh Rendaman Air Laut terhadap Kapasitas Rekatan GFRP-Sheet pada Balok Beton Bertulang. Jurnal Teknik Sipil,24(1), 31-43. https://doi.org/10.5614/jts.2017.24.1.5

Sultan, M. A., Gaus, A., Rakhman, K. A., \& Barmawi, N. 2020. Penggunaan Ekstrak Tembakau Sebagai Inhibitor Pada Beton Bertulang Menggunakan Pasir Laut dan Air Laut. Teras Jurnal, 10(1), 17-26.

Sultan, M. A., Imran, I., \& Faujan, M. 2019. Pengaruh Penambahan Limbah Pembakaran Batubara (Fly Ash) Ex Pltu Rum Pada Campuran Beton. Teras Jurnal,9(2), 83-90.

Taku, K. J., Amartey, D. Y., \& Kassar, T. 2015. Effect of Acidic Curing Environment on the Strength and Durability of Concrete. Civil and Environmental Research, 7(12), 8-13. 